\title{
Pasar Desa Digital Berbasis Web Sebagai Media Promosi Bagi UMKM
}

\author{
${ }^{1 *}$ Joko Samodra, ${ }^{2}$ Andreas Syah Pahlevi, ${ }^{3}$ Yon Ade Lose Hermanto \\ Universitas Negeri Malang; Jalan Semarang 5 Malang \\ *Corresponding author: joko.samodra.fs@um.ac.id
}

\begin{abstract}
Abstrak
Permasalahan yang dimiliki pelaku Usaha Kecil Mikro dan Menengah (UMKM) di desa Tunjungtirto kecamatan Singosari Kabupaten Malang yaitu masih menjalankan usahanya dengan sistem tradisional, belum memiliki media promosi dan pemasaran serta belum memiliki ketrampilan yang memadai dalam menggunakan media berbasis web. Tujuan kegiatan ini agar para pelaku usaha memiliki media promosi dan pemasaran yang efektif bagi peningkatan penjualan produknya. Metode pendekatannya adalah pelatihan dan pendampingan dengan konten pembuatan platform ecommerce pasar desa digital berbasis web, fungsi dan fitur media berbasis web, dan memberikan bekal ketrampilan yang memadai tentang cara menggunakan medianya. Hasil pengembangan dan evaluasi kegiatan dapat disimpulkan bahwa terdapat peningkatan pengetahuan dan ketrampilan dalam hal pembuatan, pemanfaatan media berbasis web dengan indikator telah terwujudnya media online dan sekaligus diuji coba untuk kegiatan promosi dan pemasaran produk mereka.
\end{abstract}

Kata kunci-Pasar Desa, Digital, Media Promosi, UMKM

\section{Abstract}

Problems that are owned by Micro and Medium Enterprises (SMEs) in the village of Tunjungtirto, Singosari sub-district, Malang Regency, are still running their business with traditional systems, do not have promotion and marketing media and do not yet have adequate skills in using web-based media. The purpose of this activity is for businesses to have effective promotional and marketing media to increase sales of their products. The approach method is training and mentoring with the content of making web-based digital village market ecommerce platforms, web-based media functions and features, and providing adequate skills on how to use the media. The results of the development and evaluation of activities can be concluded that there is an increase in knowledge and skills in terms of making, using web-based media with indicators that online media have been realized and at the same time being tested for promotional activities and marketing of their products.

Keywords—Village Market, Digital, Media Promotion, SMEs

\section{PENDAHULUAN}

$\mathrm{P}$ erkembangan teknologi informasi dan komunikasi saat ini memberikan dampak yang positif dalam berbagai bidang kehidupan di masyarakat, salah satunya adalah pemanfaatan media berbasis web sebagai media penyebaran informasi dan komunikasi. Pemanfaatan internet khususnya media berbasis web sudah seharusnya mendapatkan perhatian bagi para pelaku UMKM terutama untuk meningkatkan kualitas layanan data dan informasi (Andoyo \& Sujarwadi, 2017), karena media tersebut dapat menjangkau target audiens dalam skala luas, dan jumlah pengguna internet semakin bertambah besar (Lestari, 2015). Dalam hubungannya dengan era revolusi ke-4 saat ini, Samodra dan Herwanto (2019) menyatakan bahwa penggunaan media publikasi elektronik/digital telah menggeser penggunaan media cetak dan media konvensional lainnya. Walaupun dalam kondisi tertentu, penggunaan media cetak tetap tidak dapat digantikan oleh media elektronik/digital.

Berdasarkan data hasil survei APJII (2017), jumlah pengguna internet di Indonesia pada tahun 2017 telah mencapai 54,68 persen dari jumlah penduduk Indonesia yaitu sejumlah 143,26 juta pengguna dari total 262 juta penduduk Indonesia. Sebagian besar pengguna internet di Indonesia 


\section{Samodra dkk. / Jurnal Karinov Vol. 2 No. 3 (2019) 177-180}

memanfaatkan internet untuk berbagai aktifitas penting di bidang ekonomi, diantaranya untuk mencari harga produk $(45,14 \%)$, mencari informasi membeli $(37,82 \%)$, melakukan pembelian secara online $(32,19 \%)$, dan melakukan penjualan secara online $(16,83 \%)$.

Permasalahan yang dimiliki oleh para pelaku UMKM di desa Tunjungtirto kecamatan Singosari Kabupaten Malang yaitu masih menjalankan usahanya dengan sistem tradisional, belum memiliki media promosi dan pemasaran yang memadai, dan belum memiliki ketrampilan yang memadai dalam menggunakan media berbasis web untuk kegiatan promosi dan pemasaran secara online. Hal ini sama dengan permasalahan UMKM pada umumnya yaitu kurangnya penerapan inovasi teknologi sehingga omset yang didapatkan tidak bisa berkembang dengan baik (Utomo dkk., 2019; Andriyanto, 2019). Oleh karena itu dipandang perlu untuk mengembangkan sebuah media promosi dan memberikan pelatihan tentang bagaimana menggunakan media promosi tersebut, yang diwujudkan dalam bentuk sebuah platform ecommerce pasar desa digital berbasis web.

Pemilihan media e-commerce ini dianggap tepat karena didalamnya termuat teknologi dan proses bisnis yang dapat menghubungkan produsen dan konsumen melalui transaksi elektronik (Purbo \& Wahyudi, 2001), yaitu transaksi jual beli barang maupun jasa yang dilakukan melalui media internet (Suyanto, 2003). Penerapan media e-commerce pada UMKM juga sejalan dengan apa yang dinyatakan oleh Suhud dan Rezaldi (2014); Febriantoro (2018) yaitu sebagai salah satu solusi untuk mengatasi permasalahan pemasaran dan penjualan produk, karena sebagian besar UMKM di Indonesia masih melakukan kegiatan pemasaran secara konvensional.

Tujuan yang ingin dicapai dari kegiatan ini agar para pelaku UMKM di desa Tunjungtirto memiliki media promosi dan pemasaran yang memadai dan berdaya saing, mengetahui fungsi dan fitur yang dimiliki oleh media berbasis web khususnya untuk tujuan promosi dan pemasaran, dan memiliki ketrampilan yang memadai tentang cara menggunakan media berbasis web untuk kegiatan promosi dan pemasaran secara online. Pemasaran secara online merupakan salah satu metode pemasaran yang perlu dipertimbangkan oleh UMKM karena dapat dilakukan secara luas dan dapat menjangkau berbagai kalangan (Nugroho dkk, 2014; Tajuddin \& Mannan, 2017), khususnya yang secara geografis berada di tempat-tempat yang sangat jauh dan sulit untuk dijangkau dengan metode pemasaran konvensional.

\section{METODE}

Metode pemecahan masalah yang digunakan dibagi menjadi beberapa tahap yaitu (1) tahap analisis situasi, dilakukan pengumpulan data dengan cara wawancara ke sumber data yaitu kelompok UMKM Desa Tunjungtirto, (2) tahap pengembangan sistem berbasis IPTEKS yang berupa sebuah platform ecommerce pasar desa digital berbasis web, (3) tahap pembuatan materi pelatihan yang terdiri dari dua bagian utama yaitu materi pengenalan fungsi dan fitur media berbasis web untuk tujuan promosi dan pemasaran, dan panduan penggunaan media berbasis web untuk kegiatan promosi dan pemasaran secara online, (4) tahap penyampaian materi teori, (5) tahap pembimbingan praktik, (6) tahap evaluasi, dan (7) tahap pemantauan.

Kegiatan ini dilaksanakan di desa Tunjungtirto kecamatan Singosari kabupaten Malang, sedangkan tempat pelatihan dan pendampingan yaitu di balai desa Tunjungtirto dan di rumah kelompok UMKM desa Tunjungtirto. Subjek utama kegiatan ini adalah para pelaku UMKM di desa Tunjungtirto, yang jumlahnya dibatasi antara 15 hingga 20 orang. Sedangkan objek yang diteliti yaitu data produk UMKM yang diproduksi dan cara promosi atau pemasarannya.

\section{HASIL DAN PEMBAHASAN}

Kegiatan pengabdian kepada masyarakat ini telah dilaksanakan sesuai dengan tahapan yang ditetapkan. Pada tahap awal dilakukan wawancara ke sumber data yaitu Kepala Desa, Staf Desa, dan kelompok UMKM Desa Tunjungtirto. Beberapa informasi yang didapatkan diantaranya yaitu datadata UMKM yang ada di desa Tunjungtirto, jenisjenis produk yang dihasilkan, dan metode pemasaran yang dilakukan selama ini.

Tahap berikutnya dilakukan pengembangan sistem berbasis IPTEKS yang ditujukan sebagai alat bantu untuk meningkatkan kualitas promosi dan pemasaran produk-produk UMKM. Sistem ini berbentuk sebuah software pasar desa digital berbasis web dengan kerangka yang digambarkan pada Gambar 1. 
Samodra dkk. / Jurnal Karinov Vol. 2 No. 3 (2019) 177-180

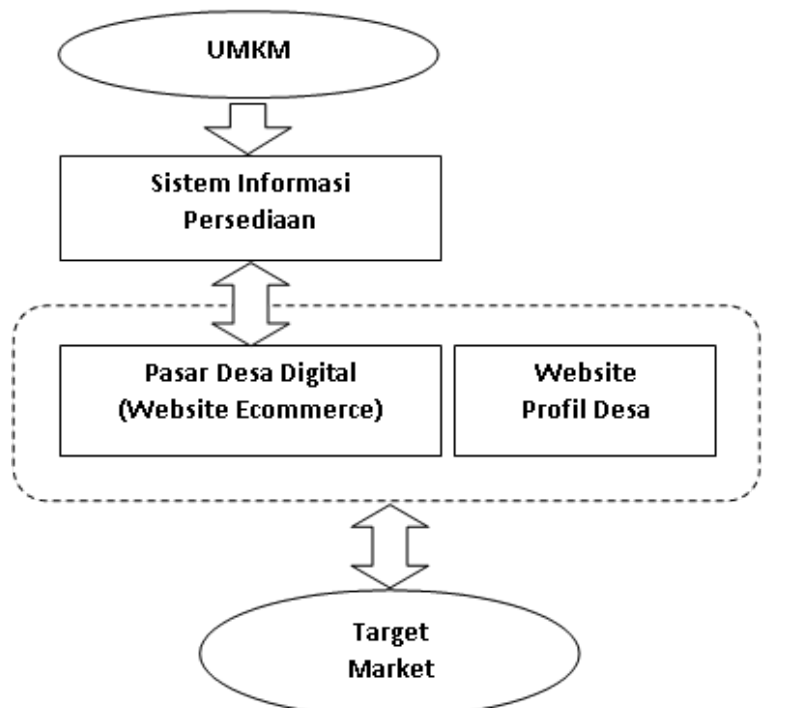

Gambar 1. Kerangka Pasar Desa Digital Berbasis Web

Sistem Informasi Persediaan merupakan sebuah software yang berfungsi untuk mengelola data persediaan produk yang berasal dari berbagai kelompok UMKM yang ada di desa Tunjungtirto. Beberapa fungsi yang disediakan oleh software ini diantaranya pengelolaan data induk produk, pengelolaan transaksi barang masuk dan barang keluar, laporan persediaan, laporan transaksi barang masuk dan barang keluar. Berikut ini adalah contoh bentuk tampilan Sistem Informasi Persediaan (Lihat Gambar 2).

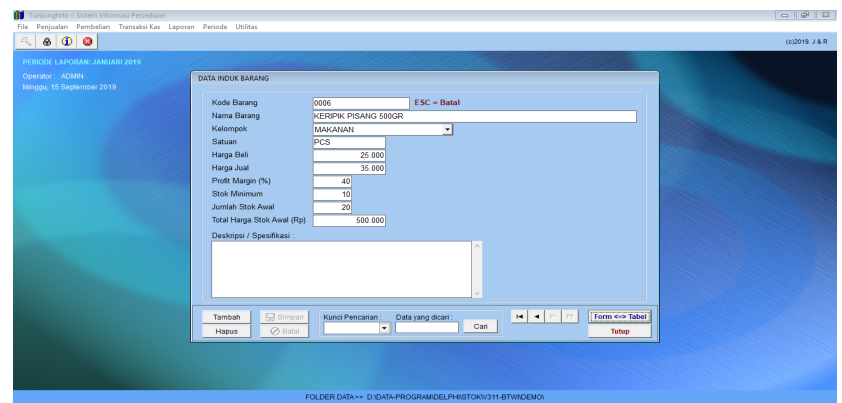

Gambar 2. Sistem Informasi Persediaan

Sedangkan software Pasar Desa Digital diwujudkan dalam sebuah website ecommerce yang berfungsi sebagai media promosi dan pemasaran produk UMKM, yaitu untuk memajang dan menangani transaksi penjualan produk ke calon konsumen. Fungsi utama yang disediakan pada website ini diantaranya yaitu katalog dan informasi detail produk, shopping cart untuk memproses transaksi penjualan, penanganan konfirmasi pembayaran, dan beberapa informasi tambahan misalnya tatacara pembelian dan halaman kontak.
Selanjutnya, contoh bentuk tampilan website Pasar Desa Digital dapat dilihat pada Gambar 3.

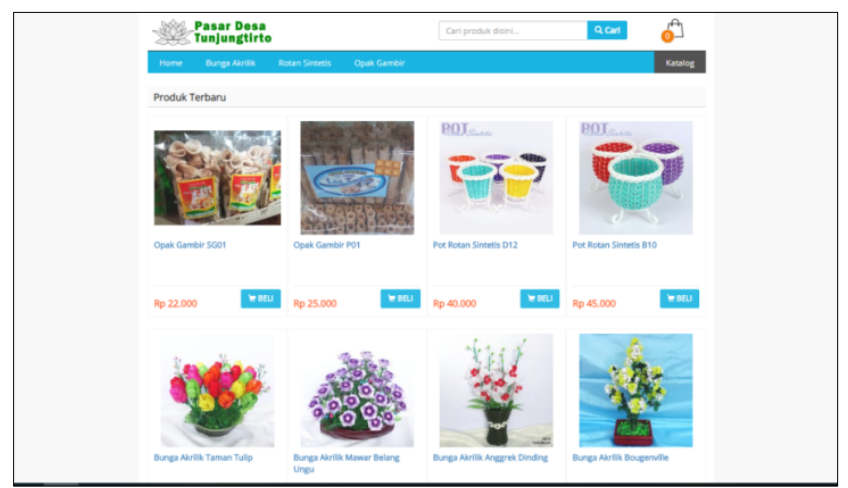

Gambar 3. Website Pasar Desa Digital

Setelah media Pasar Desa Digital selesai dikembangkan, selanjutnya diberikan pelatihan kepada para pelaku UMKM di desa Tunjungtirto yang telah dipilih sejumlah 20 orang. Materi yang disampaikan berupa pengenalan fungsi dan fitur yang dimiliki oleh media berbasis web untuk tujuan promosi dan pemasaran, diantaranya fungsi informasi, fungsi komunikasi, fungsi transaksi, domain, dan hosting. Kemudian dilanjutkan dengan praktik pengelolaan data produk UMKM melalui software persediaan dan website e-commerce. Pada tahap akhir kegiatan dilakukan evaluasi untuk menilai para peserta pelatihan khususnya dalam hal ketertiban, keterampilan, produktifitas, dan kreatifitasnya dalam menerapkan materi yang telah diberikan. Untuk memastikan bahwa para peserta pelatihan dapat menggunakan dan menerapkan keterampilan yang telah didapatkan secara berkesinambungan, maka dilakukan proses pemantauan dengan berkunjung ke rumah-rumah pelaku UMKM.

\section{SIMPULAN}

Pengembangan media Pasar Desa Digital berbasis web sebagai media promosi dan pemasaran telah dilaksanakan dan diterima dengan baik oleh para pelaku UMKM di desa Tunjungtirto kecamatan Singosari Kabupaten Malang. Para peserta sangat bersemangat dalam mengikuti pelatihan tentang fungsi dan pemanfaatan media berbasis web untuk tujuan promosi dan pemasaran secara online melalui media internet. Dari hasil evaluasi dapat diketahui bahwa setelah dilaksanakannya kegiatan ini terdapat peningkatan pengetahuan dan ketrampilan dalam hal pemanfaatan media berbasis web untuk promosi produk UMKM. 
Samodra dkk. / Jurnal Karinov Vol. 2 No. 3 (2019) 177-180

\section{UCAPAN TERIMA KASIH}

Ucapan terima kasih disampaikan kepada semua pihak yang telah memberikan dukungan baik moral maupun material dalam kegiatan pengabdian kepada masyarakat ini, khususnya kepada Universitas Negeri Malang yang telah memberikan dana PNBP sehingga kegiatan ini dapat dilaksanakan dengan baik.

\section{DAFTAR RUJUKAN}

Andoyo, A., \& Sujarwadi, A. (2017). Sistem Informasi Berbasis Web Pada Desa Tresnomaju Kecamatan Negerikaton Kab. Pesawaran. Jurnal TAM (Technology Acceptance Model), 3, 1-10.

Andriyanto, I. (2019). Penguatan Daya Saing Usaha Mikro Kecil Menengah Melalui E-Commerce. BISNIS: Jurnal Bisnis dan Manajemen Islam, 6(2), 87-100.

APJII. (2017). Penetrasi dan Perilaku Pengguna Internet Indonesia. (Online), (http://www.apjii.or.id), diakses 1 Agustus 2018.

Febriantoro, W. (2018). Kajian dan Strategi Pendukung Perkembangan E-Commerce Bagi UMKM di Indonesia. Manajerial: Jurnal Manajemen dan Sistem Informasi, 17(2), 184207.

Lestari, D. P. (2015). Analisis strategi internet marketing butik online di Surabaya melalui instagram. Commonline Departemen Komunikasi, 4(2), 412-424.

Nugroho, A., Daru, A.F., \& Adhiwibowo, W. (2014). Pengembangan Pemasaran Online Usaha Kerajinan Enceng Gondok dan Pandan di Desa Lopait Kecamatan Tuntang Kabupaten Semarang. Jurnal Transformatika, 12(1), 19-23.

Purbo, O.W., \& Wahyudi, A.A. (2001). Mengenal ECommerce. Elex Komputindo. Jakarta.

Samodra, J., \& Herwanto, A.P. (2019). Web-based Application Development For Measuring Efficiency of Information Publication Using Data Envelopment Analysis. International Journal of Advanced Research in Technology and Innovation, 1(2) 56-63.

Suhud, R., \& Rezaldi, M.Y. (2014). Pengembangan Sistem E-commerce Paguyuban Usaha Kecil dan Menengah Karya Mandiri di Tegal. Widyariset, 17(1), 49-57.

Suyanto, M. (2003). Strategi Periklanan Pada Ecommerce Perusahaan Top Dunia. Penerbit Andi. Yogyakarta.
Utomo, S.H., Qurrata, V.A., Purnamasari, V., \& Seprillina, L. (2019). Peningkatan Omset Penjualan Melalui Media Sosial Pada Usaha Kecil Menengah Alas Kaki Berbahan Kulit. Jurnal Karinov, 2(1), 57-61.

Tajuddin, M., \& Manan, A. (2017). Model Pemasaran Usaha Mikro Kecil dan Menengah (UMKM) Berbasis Online Dalam Mendukung Pariwisata. Matrik: Jurnal Manajemen, Teknik Informatika Dan Rekayasa Komputer, 17(1), 66-74. 